\title{
Aktivitas Antioksidan dan Potensi Tabir Surya Serum Ekstrak Terpurifikasi Daun Wangon (Olax psittacorum (Willd.) Vahl.)
}

\section{Antioxidant and UV Filter Activity of Wangon (Olax psittacorum (Willd.) Vahl.) Purified Extract Serum}

\author{
Reslely Harjanti, Anita Nilawati \\ Fakultas Farmasi, Universitas Setia Budi Surakarta \\ email: reslely.nindy@gmail.com
}

(tanggal diterima: 03-02-2020 , tanggal disetujui: 12-03-2020)

\section{INTISARI}

Perkembangan sediaan kosmetika herbal saat ini semakin pesat. Salah satunya adalah serum yang disukai masyarakat karena lebih nyaman digunakan dan lebih mudah menyebar di permukaan kulit. Pada umumnya serum mengandung senyawa antioksidan yang poten sebagai anti aging di mana formulanya dikaitkan dengan komponen antioksidan di dalamnya. Ekstrak etanol daun wangon telah diteliti mengandung senyawa golongan flavonoid yang mempunyai potensi antioksidan. Penelitian ini bertujuan untuk membuat ekstrak terpurifikasi daun wangon selanjutnya dibuat sediaan kosmetika serum yang diuji mutu fisik dan stabilitas antioksidannya serta dilakukan pengujian terkait potensinya sebagai tabir surya sehingga diharapkan dapat dilakukan inovasi terhadap sediaan serum yang dihasilkan.

Penelitian diawali dengan pembuatan ekstrak dengan pelarut etanol 96\%. Selanjutnya dilakukan fraksinasi terhadap ekstrak kasar dengan metode ekstraksi cair-cair yang berturut-turut menggunakan pelarut n-heksana dan etil asetat. Kandungan flavonoid dalam ekstrak terpurifikasi dimonitoring secara KLT. Selanjutnya dibuat formulasi sediaan serum dengan 1,1 \% zat aktif ekstrak terpurifikasi daun wangon dan dilakukan uji mutu fisik terhadap sediaan tersebut meliputi organoleptis, $\mathrm{pH}$, viskositas dan homogenitasnya. Selanjutnya ekstrak terpurifikasi dan sediaan serum diuji aktivitas antioksidannya dengan metode DPPH dan penentuan aktivitas sebagai tabir surya dengan parameter nilai SPF.

Hasil penelitian menunjukkan bahwa ekstrak terpurifikasi daun wangon mempunyai nilai $\mathrm{IC}_{50} 41,98 \mu \mathrm{g} / \mathrm{mL}$ lebih baik jika dibandingkan dengan ekstrak kasar dengan $\mathrm{IC}_{50} 65,32 \mu \mathrm{g} / \mathrm{mL}$. Sediaan serum mempunyai nilai $\mathrm{IC}_{50} 71,30 \mu \mathrm{g} / \mathrm{mL}$ dan tergolong antioksidan kuat. Setelah sediaan disimpan selama 30 hari potensi antioksidannya tetap stabil. Selain itu serum tersebut juga mempunyai potensi sebagai tabir surya dengan nilai SPF 19,50 $\pm 0,02$ yang kategorikan memberikan perlindungan menengah terhadap sinar UV B.

\section{Kata kunci : Antioksidan; Daun Wangon; Serum; Tabir Surya}

\section{ABSTRACT}

The development of herbal cosmetic products are currently increasing rapidly. One of them is a serum that is preferred by the community because it is more comfortable to use and easier to spread on the surface of the skin.. In general, serum contains antioxidant compounds that are potential as anti-aging in which the formula associated with antioxidant components in it. Ethanol extracts of wangon leaves have been studied to contain flavonoid compounds which have antioxidant potential. This research aims to make purified extracts of wangon leaves and then make serum cosmetic preparations that are tested for their physical quality and antioxidant stability and to test their potential as a sunscreen so that innovation can be expected to be produced.

The study began with extracts made with $96 \%$ ethanol solvent. Subsequently, fractination has been carried out on crude extracts using liquid-liquid extraction methods, which successively use n-hexane and ethyl acetate solvents. The flavonoid content in purified extracts was monitored with TLC. Furthermore, a serum formulation was made with purified extract of wangon leaf extract and physical quality tests were carried out on the preparation including organoleptic, $\mathrm{pH}$, viscosity 
and homogeneity. Furthermore, purified extracts and serum preparations were tested for their antioxidant activity by DPPH method and UV-Vis spectrophotometric determination.

The results showed that purified leaves of wangon leaves had IC50 values of $41.98 \mu \mathrm{g} / \mathrm{mL}$ better when compared to crude extracts with IC50 $65.32 \mu \mathrm{g} / \mathrm{mL}$. Serum preparations had an IC50 value of $71.30 \mu \mathrm{g} / \mathrm{mL}$ and were classified as potent antioxidants. After the preparation has been stored for 30 days, the antioxidant remains stable. In addition, the serum also had potential as a UV filter with an SPF value of $19.50 \pm 0.02$ which has been categorized as providing medium protection against UV B.

\section{Keyword : Antioxidant, Wangon Leaves; Serum; UV Filter}

\section{PENDAHULUAN}

Daun wangon (Olax psittacorum (Wild.) Vahl.) di beberapa daerah di Indonesia dikenal sebagai sayuran hijau (green leafy vegetables). Penelitian terkait daun wangon belum banyak dilakukan di Indonesia karena memang daun tersebut hanya dapat ditemui di daerah tertentu misalnya di sekitar hutan jati. Penelitian sebelumnya melaporkan bahwa kandungan senyawa di dalam daun wangon antara lain fenolik khususnya flavonoid serta tanin. Kadar fenolik total dalam 1 gram ekstrak metanol daun wangon adalah 95,68 dalam mg setara asam galat, sedangkan kadar flavonoid totalnya 713,33 dalam mg setara kuersetin dan kadar tanin totalnya 15,28 mg dalam mg setara asam tanat [1]. Menurut laporan penelitian lainnya [2], ekstrak etanol daun wangon mempunyai aktivitas penangkap radikal bebas DPPH lebih besar daripada ekstrak metanol. Etanol 96\% menghasilkan potensi antioksidan yang lebih baik daripada etanol $70 \%$ [3].

Kosmetik herbal saat ini mulai banyak dikembangkan di mana salah satu komponennya adalah antioksidan. Antioksidan sintetik yang sudah biasa digunakan dalam produk kosmetik seperti butylated hydroxyanisole (BHA), butylated hydroxytoluene (BHT) dan propil galat dapat menyebabkan atau mempromosi efek negatif bagi kesehatan [4][5]. Sehingga penggunaan senyawa alam diharapkan berpotensi sebagai alternatif pengganti antioksidan sintetis. Kebanyakan antioksidan adalah flavonoid, isoflavon, kumarin, lignin, antosianin, flavon dan isokatekin [6].

Senyawa polifenol seperti senyawa flavonoid mampu menghambat autooksidasi melalui mekanisme penangkapan radikal bebas (radical scavenging) dengan cara menyumbangkan satu elektron dari elektron yang tidak berpasangan dalam radikal bebas sehingga banyaknya radikal bebas berkurang [7]. Senyawa fenolik adalah senyawa penyusun yang keberadaannya luas dalam tanaman dan telah dipercaya mempunyai kapasitas antioksidan dan penangkap radikal bebas yang tinggi [8].

Sediaan kosmetika telah berkembang menjadi berbagai bentuk sediaan yang pada prinsipnya bertujuan untuk meningkatkan kenyamanan dan manfaatnya. Salah satu sediaan kosmetika yang berkembang saat ini adalah 
serum. Serum merupakan sediaan dengan zat aktif konsentrasi tinggi dan viskositas rendah, yang menghantarkan film tipis dari bahan aktif pada permukaan kulit [9]. Serum diformulasikan dengan viskositas yang rendah dan kurang jernih (semitransparan), yang mengandung kadar bahan aktif yang lebih tinggi dari sediaan topikal pada umumnya. Kelebihan serum adalah dapat memberikan efek yang lebih nyaman dan lebih mudah menyebar di permukaan kulit. Pada umumnya sediaan kosmetika serum mengandung komponen antioksidan yang berpotensi untuk mencegah penuaan dini (anti aging).

Aktivitas antioksidan senyawa dapat diukur dari kemampuannya menangkap radikal bebas. Salah satu parameter untuk interpretasi hasil uji aktivitas antioksidan dengan metode DPPH adalah nilai EC50 atau umumnya disebut nilai IC50 yang didefinisikan sebagai konsentrasi sampel yang menyebabkan hilangnya 50\% aktivitas DPPH yang ditunjukkan dengan perubahan warna [10].

Mengacu pada penelitian terdahulu maka perlu dilakukan purifikasi terhadap ekstrak etanol daun wangon berdasarkan pada target senyawa yang berpotensi sebagai antioksidan untuk tujuan isolasi. Selanjutnya dibuat sediaan kosmetik serum dan ditentukan stabilitas antioksidannya. Selain juga perlu ditetapkan potensinya sebagai tabir surya sehingga dapat dilakukan inovasi sediaan kosmetika serum sebagai tabir surya masih belum banyak dilakukan.

Potensi menahan sinar ultraviolet dari tabir surya dinilai dalam faktor proteksi sinar (Sun Protecting Factor / SPF) yaitu perbandingan energi ultraviolet yang diperlukan untuk menghasilkan eritema minimum pada kulit yang diberi tabir surya terhadap banyaknya energi ultraviolet yang diperlukan untuk menghasilkan erythema minimum pada kulit yang tidak diberi tabir surya. Minimal erythema dose (MED) adalah dosis energi minimum ultraviolet yang diperlukan untuk menghasilkan eritema kulit minimum yang seragam. Nilai MED berbeda beda berdasarkan tipe kulit seseorang [11].

\section{METODE PENELITIAN}

\section{1. ALAT DAN BAHAN}

Alat yang digunakan adalah spektrofotometer UV Vis (Shimadzu 1800), neraca analitik (Ohaus), oven (Memmert), viskometer stormer, pH meter tipe 510 (Eutech Instruments), seperangkat alat KLT, alat-alat gelas yang lain. Bahan yang digunakan adalah daun wangon, DPPH (Sigma Aldrich), etanol p.a (Merck), etanol 96\%, n-heksana, etil asetat, reagen untuk identifikasi golongan senyawa, fase gerak n-butanol:asam asetat:air (4:1:5)[16], amonia, natrosol®, gliserin, DMDM Hidantoin, etoksidiglikol, kuersetin (Sigma Aldrich), aqua demineralisata, aqua destillata. 


\section{2. CARA KERJA}

\section{Pengambilan dan Determinasi Tanaman.}

Daun wangon diambil dari kelurahan Ngelo, kecamatan Cepu, kabupaten Blora Jawa Tengah pada bulan Agustus 2019. Selanjutnya tanaman dideterminasi di laboratorium MIPA Universitas Sebelas Maret.

\section{Pembuatan Ekstrak Etanol dan Ekstrak Terpurifikasi Daun Wangon.}

Ekstrak etanol 96\% daun wangon diperoleh dengan metode maserasi selanjutnya ekstrak tersebut diekstraksi cair-cair dengan pelarut berturut turut nheksana dan etil asetat. Proses tersebut dilakukan sebanyak 3 kali pengulangan. Selanjutnya fase etil asetat diuapkan pelarutnya hingga kental[17].

\section{Identifikasi Golongan Senyawa Kimia dan Flavonoid.}

Ekstrak kasar diidentifikasi dengan reaksi tabung meliputi senyawa flavonoid, saponin, fenolik, dan tannin. Sedangkan identifikasi flavonoid dalam ekstrak terpurifikasi dilakukan secara Kromatografi Lapis Tipis (KLT) dengan fase gerak n-butanol:asam asetat:air (4:1:5). Bercak dideteksi pada sinar UV 254 dan 366 nm serta diuapi amonia.

\section{Penentuan SPF Ekstrak untuk Pembuatan Serum.}

Penentuan nilai sun protection factor (SPF) dilakukan berdasarkan pada konsentrasi tertentu hingga diperoleh nilai SPF sampai 30 dengan absorbansi minimal 0,05. Penentuan nilai SPF ini bertujuan untuk mengetahui jumlah sampel yang ditimbang yang akan digunakan untuk formulasi. Pengujian dilakukan secara in vitro dengan menggunakan spektrofotometer UV. Pengukuran nilai SPF dilakukan dengan cara ekstrak diukur serapannya tiap $5 \mathrm{~nm}$ pada rentang panjang gelombang antara 280-320 nm yang memiliki nilai serapan minimal 0,05. Selanjutnya area di bawah kurva dihitung $5 \mathrm{~nm}$ dari jumlah serapan pada panjang gelombang ke-n dan panjang serapan pada gelombang ke (n-1) dibagi 2 dikali 5 [12]. Formulasi Serum Ekstrak Terpurifikasi Daun Wangon.

Formulasi serum ekstrak terpurifikasi daun wangon dibuat dengan formula basis terbaik berdasarkan penelitian [6] dengan modifikasi dan penambahan zat aktif dengan konsentrasi yang mampu menghasilkan nilai SPF yang diinginkan berdasarkan perhitungan yaitu SPF 30 dengan formula pada Tabel 1.

Tabel 1. Formula serum ekstrak terpurifikasi daun wangon

\begin{tabular}{clcc}
\hline No & \multicolumn{1}{c}{ Bahan } & Fungsi & Konsentrasi (\%) \\
\hline 1 & Ekstrak Terpurifikasi & Antioksidan dan UV filter & 1,1 \\
2 & Natrosol & Gelling agent & 0,05 \\
3 & Vegetable Gliserin & Humektan & 0,2 \\
4 & DMDM Hydantoin & Pengawet & 5 \\
5 & Ethoxydiglycol & Penetran & 5 \\
6 & Parfum & Pewangi & 0,5 \\
8 & Aqua DM & Pelarut & Sampai 100 \\
\hline
\end{tabular}




\section{Uji Mutu Fisik Serum.}

Uji mutu fisik sediaan kosmetika serum meliputi organoleptis, $\mathrm{pH}$, viskositas, dan homogenitas. Pengujian organoleptik dilakukan dengan mengamati warna dan bau sediaan yang dibuat. Penentuan derajat keasaman $(\mathrm{pH})$ dilakukan menggunakan $\mathrm{pH}$ meter yang terlebih dahulu dikalibrasi dengan larutan dapar standar pH 4 dan 7. Uji viskositas menggunakan viskometer. Pengamatan homogenitas dilakukan dengan mengamati sebaran partikel serum yang dioleskan pada kaca objek dan dijepit dengan cover glass, lalu diamati menggunakan mikroskop untuk melihat kehomogenan serum yang dibuat. Sediaan disimpan selama 30 hari dan diamati juga mutu fisiknya.

\section{Uji Aktivitas Antioksidan.}

Pengujian dimulai dengan tahapan penetapan kondisi analisis yaitu dengan penentuan panjang gelombang $(\lambda)$ maksimum dan penetapan operating time. Selanjutnya aktivitas antioksidan dari ekstrak dan masing-masing formula ditentukan dengan metode DPPH. Sebagai kontrol digunakan larutan DPPH dan pembanding yang digunakan adalah kuersetin. Pengujian dilakukan dengan tiga kali pengulangan.

Selanjutnya data absorbansi yang diperoleh dimasukkan ke dalam persamaan regresi. Nilai $I_{50}$ dari perhitungan adalah pada saat \% inhibisi sebesar $50 \%$ dengan rumus persamaan regresi linier : $y=b x+a$. Suatu senyawa dikatakan sebagai antioksidan sangat kuat jika nilai IC 50 kurang dari 50, kuat (50-100), sedang (100-150), dan lemah (151-200). Semakin kecil nilai IC50 semakin tinggi aktivitas antioksidan [13]. Aktivitas penangkap radikal DPPH dihitung dengan menggunakan rumus persen penangkapan radikal bebas, selanjutnya data yang diperoleh diolah dengan persamaan regresi linier untuk menentukan $\mathrm{IC}_{50}$.

\section{Penentuan Nilai SPF sebagai Parameter Tabir Surya.}

Penentuan nilai SPF secara in vitro dilakukan dengan metode spektrofotometri UV. Ekstrak kasar, ekstrak terpurifikasi dan sediaan kosmetika serum masing-masing ditimbang sebanyak $\pm 1,0$ gram kemudian dimasukkan ke dalam labu tentukur $100 \mathrm{~mL}$ dan dilarutkan dengan etanol. Kalibrasi spektrofotometer UV-Vis terlebih dahulu dengan menggunakan etanol sebanyak 1 $\mathrm{mL}$, kemudian kuvet dimasukkan ke dalam spektrofotometer UV-Vis. Larutan hasil pengenceran dari masing-masing sampel yang dibuat dihitung serapannya dan nilai SPF nya. Dilakukan uji sebanyak 3 kali untuk mendapatkan nilai yang akurat dan dihitung menggunakan persamaan [14]:

$$
\text { Nilai } S P F=C F x \sum_{320}^{290} A b s x E E x I
$$

Di mana: $\quad \mathrm{EE} \quad=$ Spektrum efek eritemal

I = Intensitas spektrum sinar

Abs = Serapan produk tabir

$\mathrm{CF} \quad=$ Faktor koreksi [10] 
Nilai EE x 1 adalah suatu konstanta. Nilainya diperoleh dari panjang gelombang 290$320 \mathrm{~nm}$ dan setiap selisih $5 \mathrm{~nm}$ telah ditentukan seperti ditunjukkan pada Tabel $2[14]$.

Tabel 2. Nilai EE x 1 pada panjang gelombang 290-320 nm

\begin{tabular}{lc}
\hline Panjag gelombang $(\mathrm{nm})$ & EE x I \\
\hline 290 & 0,0150 \\
295 & 0,0817 \\
300 & 0,2874 \\
305 & 0,3278 \\
310 & 0,1864 \\
315 & 0,0839 \\
320 & 0,0180
\end{tabular}

Nilai SPF berkisar antara 0 sampai 100, dan kemampuan tabir surya yang dianggap baik berada di atas 15 [11].

\section{HASIL DAN PEMBAHASAN}

\section{Pengambilan Dan Determinasi Tanaman.}

Hasil determinasi yang telah dilakukan menunjukkan bahwa tanaman yang digunakan untuk penelitian adalah Olax psittacorum (Wild.) Vahl.. Determinasi bertujuan untuk memastikan bahwa tanaman yang digunakan benar-benar tanaman wangon.

Pembuatan Ekstrak Etanol dan Ekstrak Terpurifikasi.

Ekstrak terpurifikasi yang diperoleh berwarna hijau kental dengan kadar air $20 \% \pm 0,02$ memenuhi syarat. Rendemen ekstrak terpurifikasi yang diperoleh yaitu $24,8 \% \pm 0,00$.

\section{Identifikasi Golongan Senyawa Dan Flavonoid.}

Berdasarkan hasil uji golongan senyawa, ekstrak kasar mengandung senyawa flavonoid, saponin, fenolik dan tanin. Ekstrak terpurifikasi daun wangon mengandung senyawa yang sama dengan ekstrak kasar dan selanjutnya diidentifikasi kandungan flavonoidnya secara KLT, karena yang diduga mempunyai potensi antioksidan adalah flavonoid mengacu pada penelitian sebelumnya [1][2][3]. Hasil identifikasi dengan pembanding kuersetin disajikan dalam Gambar 1.

Ekstrak terpurifikasi daun wangon mengandung flavovoid jenis kuersetin yang dapat dilihat dari nilai Rf yang hampir sama di mana Rf ekstrak terpurifikasi 0,7 sedangkan Rf standar kuersetin 0,72.

Penentuan Nilai SPF Ekstrak Terpurifikasi untuk Pembuatan Sediaan Serum. Ekstrak terpurifikasi perlu ditentukan proporsinya berdasarkan perhitungan dengan persamaan Mansur, supaya sediaan kosmetika serum mampu menghasilkan 
nilai SPF yang dikehendaki yaitu 30. Hasil perhitungan menunjukkan bahwa perlu ditimbang ekstrak terpurifikasi daun wangon sebanyak $66 \mathrm{mg}$.

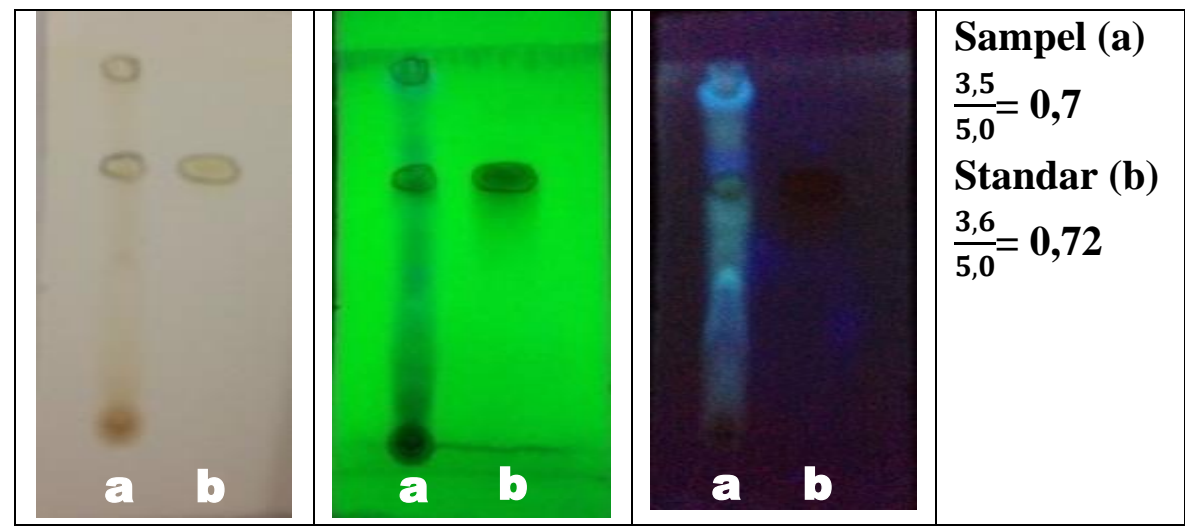

Gambar 1. Hasil Uji Flavonoid Ekstrak Terpurifikasi Daun Wangon secara KLT

\section{Uji Mutu Fisik Sediaan Serum.}

Hasil pengujian organoleptik yaitu warna semi transparan (keruh), bau lemah, tampilan agak kental dan homogen yang ditunjukkan pada gambar 2 . Pengamatan homogenitas dilakukan dengan mengamati sebaran partikel serum yang dioleskan pada kaca objek dan dijepit dengan cover glass, lalu diamati menggunakan mikroskop untuk melihat kehomogenan serum yang dibuat. Penentuan derajat keasaman $(\mathrm{pH})$ dilakukan menggunakan $\mathrm{pH}$ meter yang terlebih dahulu dikalibrasi dengan larutan dapar standar $\mathrm{pH} 4$ dan 7. Nilai pH sediaan kosmetika serum yang dibuat adalah 7,32. Penentuan $\mathrm{pH}$ bertujuan untuk mengetahui $\mathrm{pH}$ serum yang dibuat telah memenuhi syarat atau tidak, yaitu antara 4,5 - 8,0. Uji pH dilakukan untuk mengetahui serum sudah memenuhi standar yang berlaku yaitu SNI antara 4,5-8,0. Pengukuran ini bertujuan untuk mengetahui cocok tidaknya sediaan jika diaplikasikan pada kulit. Serum yang terlalu asam atau basa akan menimbulkan iritasi pada kulit. Viskositas sediaan serum adalah $58.33 \pm 2.89$ Setelah penyimpanan selama 30 hari sediaan masih mempunyai $\mathrm{pH}$ yang sama yaitu 7,32 dan homogen dengan penurunan viskositas menjadi 45.00 \pm 1.73 . Hasil uji mutu fisik sediaan serum disajikan pada tabel 3. Secara umum sediaan yang dihasilkan belum layak untuk digunakan karena belum dilakukan uji hedonik/uji kesukaan yang melibatkan panelis serta pengujian lainnya yang mendukung stabilitas dan keamanan sediaan sehingga sediaan dapat diproduksi dan dikomersilkan.

\section{Uji Aktivitas Antioksidan.}

Pengujian persen peredaman terhadap DPPH dilakukan pada ekstrak etanol, ekstrak terpurifikasi, pembanding kuersetin dan sediaan serum daun wangon. Kemudian dilanjutkan dengan perhitungan aktivitas antioksidan dengan parameter IC50. Tabel 4 berikut ini menyajikan nilai IC50 dari masing-masing sampel. 
Tabel 3. Hasil uji mutu fisik serum ekstrak terpurifikasi daun wangon

\begin{tabular}{clccc}
\hline Sampel & \multicolumn{1}{c}{ Warna } & Homogenitas & pH & $\begin{array}{c}\text { Viskositas } \\
(\mathrm{dPas})\end{array}$ \\
\hline Serum baru dibuat & $\begin{array}{l}\text { Semi transparan } \\
\text { kuning kehijauan, } \\
\text { agak kental }\end{array}$ & Homogen & 7,32 & $58,33 \pm 2,89$ \\
$\begin{array}{l}\text { Serum setelah } \\
\text { penyimpanan }\end{array}$ & $\begin{array}{l}\text { Semi transparan } \\
\text { kuning kehijauan, } \\
\text { agak kental }\end{array}$ & Homogen & 7,32 & $45,00 \pm 1,73$ \\
\hline
\end{tabular}

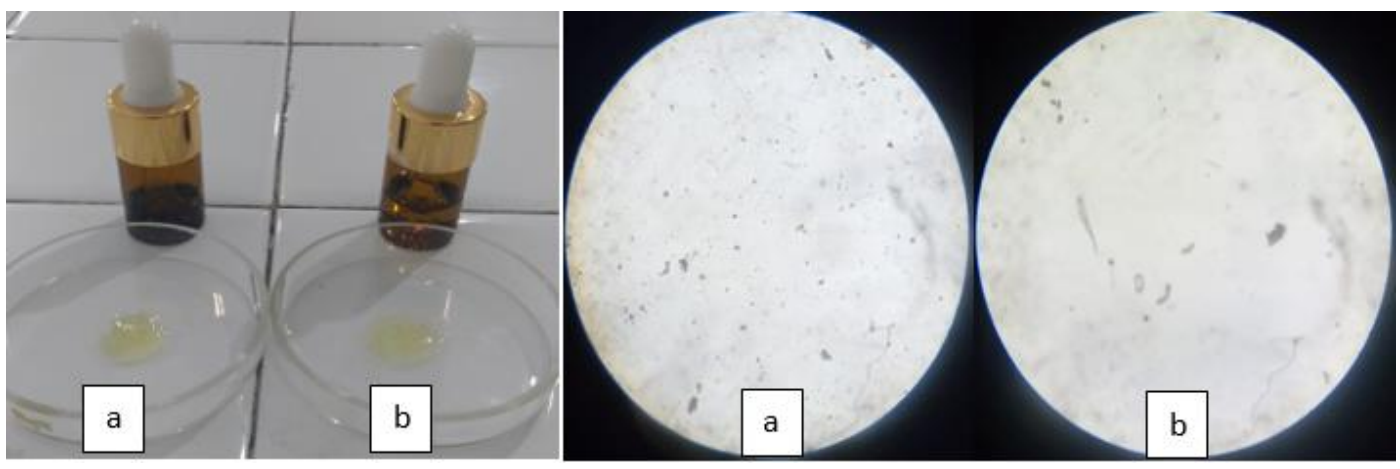

Gambar 2. Serum ekstrak terpurifikasi daun wangon dan uji homogenitas : a) sebelum penyimpanan, b) setelah penyimpanan

Tabel 4. Nilai IC 50 ekstrak etanol, ekstrak terpurifikasi daun wangon dan standar kuersetin

\begin{tabular}{lc}
\hline \multicolumn{1}{c}{ Sampel } & $\mathrm{IC}_{50}(\mathrm{ppm})$ \\
\hline & \\
Ekstrak etanol 96\% daun wangon & 65,32 \\
Ekstrak terpurifikasi & 41,98 \\
Kuersetin & 2,55 \\
Sediaan kosmetika serum daun wangon & 71,30 \\
Sediaan kosmetika serum daun wangon disimpan & 77,36 \\
30 hari pada suhu kamar & \\
\hline
\end{tabular}

Nilai IC50 menunjukkan bahwa ekstrak terpurifikasi daun wangon mempunyai potensi antioksidan yang lebih kuat dibandingkan dengan ekstrak kasarnya. Sayuran hijau mempunyai potensi sebagai antioksidan karena mengandung vitamin C, flavonoid, karotenoid[18]. Senyawa antioksidan dalam sayuran hijau bekerja dengan secara signifikan memperlambat atau mencegah oksidatif atau kerusakan dari proses oksigen yang disebabkan oleh radikal bebas seperti radikal superoksida $\left(\mathrm{O}_{2}\right)$, Radikal hidroksil $(\mathrm{OH})$ dan spesies radikal tidak bebas seperti $\mathrm{H}_{2} \mathrm{O}_{2}$ dan oksigen singlet $\left({ }^{1} \mathrm{O}_{2}\right)$ [19].

Setelah diformulasikan menjadi sediaan serum aktivitas antioksidannya sedikit menurun. Aktivitas antioksidan yang tidak stabil selama diformulasi dan penyimpanan kemungkinan karena beberapa hal antara lain akibat interaksi dengan basis serum di mana pada sediaan tidak ditambah dengan antioksidan lain 
yang dapat mencegah kerusakan serum akibat reaksi oksidasi, sehingga ekstrak juga bertindak sebagai antioksidan dalam sediaan [15]. Kelemahan jika ditambah dengan antioksidan sintetik dalam formulanya adalah diduga akan berpengaruh pada uji aktivitas antioksidannya. Sehingga dapat disimpulkan bahwa sebaiknya perlu dilakukan optimasi basis sediaan serum sebelum digunakan. Sehingga diperoleh basis yang stabil yang sesuai untuk ekstrak suatu simplisia.

\section{Penentuan Nilai SPF sebagai Parameter Tabir Surya.}

Nilai SPF merupakan salah satu parameter yang menyatakan bahwa sampel mempunyai potensi sebagai UV filter atau tidak. Penentuan nilai SPF dapat ditentukan secara spektrofotometri UV. Tabel 5 berikut ini menyajikan hasil perhitungan nilai SPF sampel sediaan kosmetika serum dan sediaan kosmetika serum setelah disimpan selama 30 hari pada suhu kamar.

Tabel 5. Nilai SPF ekstrak terpurifikasi, sediaan serum daun wangon dan sediaan yang telah disimpan selama 30 hari pada suhu kamar.

\begin{tabular}{lc}
\hline \multicolumn{1}{c}{ Sampel } & SPF \\
\hline Ekstrak etanol & $27,06 \pm 0,04$ \\
Ekstrak terpurifikasi daun wangon & $25,09 \pm 0,26$ \\
Sediaan serum daun wangon & $19,50 \pm 0,01$ \\
Sediaan serum yang telah disimpan 30 hari & $10,55 \pm 0,02$ \\
\hline
\end{tabular}

Hasil pengukuran nilai SPF menunjukkan bahwa ekstrak terpurifikasi daun wangon mempunyai potensi sebagai UV filter tingkat menengah/medium. Pada saat akan dibuat formulasi sudah dihitung sampel yang dibutuhkan untuk menghasilkan nilai SPF yang diinginkan yaitu SPF 30. Tetapi setelah dilakukan pengukuran pada sediaan jadi ternyata nilai SPF yang diperoleh adalah $19,50 \pm 0,01$. Sediaan serum yang dihasilkan selanjutnya disimpan selama 30 hari pada suhu kamar dan kembali ditentukan nilai SPFnya. Ternyata hasilnya adalah terjadi penurunan nilai SPF menjadi $10,55 \pm 0,02$. Hal ini menunjukkan bahwa senyawa aktif yang berpotensi sebagai tabir surya (UV filter) mengalami kerusakan selama proses penyimpanan. Beberapa fitokonstituen salah satunya flavonoid mempunyai potensi sebagai tabir surya karena adanya gugus kromofor. Gugus kromofor tersebut merupakan sistem aromatik terkonjugasi yang menyebabkan kemampuan untuk menyerap kuat sinar pada kisaran panjang gelombang sinar UV baik pada UVA maupun UVB. Senyawa alam umumnya tidak stabil pada beberapa kondisi penyimpanan [15]. Senyawa flavonoid tidak stabil terhadap perubahan pengaruh oksidasi, cahaya, dan perubahan kimia, sehingga apabila teroksidasi strukturnya akan berubah dan fungsinya sebagai bahan aktif akan menurun bahkan hilang dan kelarutannya rendah[20]. Sehingga jika dikembangkan pada penelitian selanjutnya maka perlu ditentukan stabilitas sediaan. 


\section{KESIMPULAN}

Ekstrak terpurifikasi daun wangon mempunyai aktivitas antioksidan yang lebih baik dengan Nilai IC 50 41,98 mg/mL dibandingkan dengan ekstrak kasarnya. Setelah diformulasikan menjadi sediaan kosmetika serum mempunyai Nilai IC $_{50}$ $71,30 \mathrm{mg} / \mathrm{mL}$ dan dalam penyimpanannya pada suhu kamar selama 30 hari aktivitas antioksidannya masih stabil. Sediaan serum ekstrak terpurifikasi daun wangon mempunyai potensi sebagai UV Filter terutama pada UV B dengan nilai SPF $19,50 \pm 0,02$.

\section{UCAPAN TERIMAKASIH}

Terimakasih penulis sampaikan kepada Universitas Setia Budi Surakarta yang telah mendanai penelitian ini pada skema penelitian dasar tahun pendanaan 2019.

\section{DAFTAR PUSTAKA}

[1]. Majumder, R. Dhara, M., Adhikari, L. 2015. Comparative Study of Leaves and Stem Methanolic Extract on Antioxidant and Antimicrobial Activity through Quantitative Evaluation of Phytoconstituents, International Journal of Engineering Technology, Management and Applied Sciences. Vol.3, 208-216.

[2]. Rajani K, S., Manoranjan K., Rasmirani R. 2013. DPPH Free Radical Scavenging Activity of Some Leafy Vegetables used by Tribals of Odisha, India. Journal of Medicinal Plants Studies. Vol: 1, issue 4. DOI: 10.22271/plants

[3]. Harjanti, R., Aisiyah, S., Nopiyanti, V. 2018. The Effectiveness Of Solvent Proportions On Antioxidant Properties Of Wangon (Olax Psittacorum (Wild.) Vahl.) Leaves, Jurnal Media Farmasi Indonesia, Vol 13 No. 2.

[4]. Karori, S.M., Wachira. F.N., Wanyoko, J.K., and Ngure, R.M., 2007, AntioxidantCapacity of Orthosiphon stamineus Benth from Different GeographicalOrigin, Journal of Sustainability Science and Management, 2006. Vol. 1[2]: pp 14-20.

[5]. Pourmorad, F., Hosseinimehr, S.J., and Shahabimajd, N., 2006, Antioxidant Activity, Phenol and Flavonoid Content some Selected Iranian MedicinalPlants, African Journal of Biotechnology, Vol. 5 [11], pp. 1142-1145. DOI:10.5897/AJB06.168

[6]. Yanni D. M., Hanna Y., Deny P. A, Rusdiana, T., 2018, Formulasi dan Stabilitas Sediaan Serum dari Ekstrak Kopi Hijau (Coffea Canephora Var. Robusta) sebagai Antioksidan, Indonesia Natural Research Pharmaceutical Journal, pp 19-33.

[7]. Pokorny, J. (Ed.), 2003. Chapter 1. Antioxidants in food: practical applications, Reprint. ed, Woodhead publishing in food science and technology. Woodhead, Cambridge. pp 42- 50

[8]. Kahkonen, M. P., Hopia, A. I., Vuoreia, H. J., Rauha, J.P., Pihlaja, K., Kujala, T. S., and Heinonen M., 2001, Antioxidant Activity of Extract Containing Phenolic Compounds, J. Agric.FoodChem., 47, 3954-3962. 
[9]. Draelos, Z.D. 2010. Cosmetic Dermatology Products and Procedures. USA: Blackwell Publishing, Ltd

[10]. Molyneux, P. 2004. The Use of the Stable Free Radical Diphenylpicrylhydrazyl (DPPH) for Estimating Antioxidant Activity. Journal Science Technology. 26 [2]: pp 212

[11]. Nguyen, N., \& Rigel, D.S., 2005, Photoprotection and the Prevention of Photocarcinogenesis. In Sunscreens: Regulation and Commercial Development. Eds: Shaat, N.A. Third Edition. Department of Dermatology. New York University School of Medicine. New York. USA. pp 157-159.

[12]. Yuliani S.H., 2010. Optimasi kombinasi campuran sorbitol, gliserol dan propilenglikol dalam gel suncreen ekstrak etanol Curcuma mangga. Majalah farmasi indonesia. 2: pp 83-89

[13]. Badarinath A, Rao K, Chetty CS, Ramkanth S, Rajan T, \& Gnanaprakash K. 2010. A Review on In-vitro Antioxidant Methods : Comparisons, Correlations, and Considerations. International Journal of PharmTech Research, pp 12761285.

[14]. Dutra E.A., Daniella A.G., Erika Rosa M.K, Maria I.R. 2004. Determination of sun protection factor (SPF) of sunscreens by ultraviolet spectrophotometry. Brazilian Journal of Pharmaceutical Sciences. Vol. 40 [3].

[15]. Prasiddha, I.J., Rosalina A.L., Teti E.dan Jaya M. M., 2015, Potensi senyawa bioaktif rambut jagung (Zea mays L.) untuk tabir surya alami: kajian pustaka. Jurnal Pangan Dan Agroindustri. Vol. 4[1] : pp 40-45.

[16]. Yohanes Adithya Koirewoa, Y.A., Fatimawali, F., Wiyono, W., 2012. Isolasi Dan Identifikasi Senyawa Flavonoid Dalam Daun Beluntas (Pluchea Indica L.), Pharmacon, Vol. 1 No. 1.

[17]. Zhang, F., Chen, B., Xiao, S., Yao, S.Z. 2004. Optimization and Comparison of Different Extraction Techniques for Sanguinarine and Chelerythrine in Fruits of Macleaya cordata (Willd) R Br. Separation and Purification Technology. 283-290.

[18]. Gerber, M., Boutron-Ruault, MC., Hercberg, S., Riboli, E., Scalbert, A., Siess MH. 2002 Food \& Cancer: State of The Art About The Protective Effect of Fruits and Vegetables. Bulletin du Cancer. Vol. 89, Issue.3, pp:293-312.

[19]. Sahu, R.K., Kar, M., Routray, R., 2013. DPPH Free Radical Scavenging Activity of Some Leafy Vegetables used by Tribals of Odisha, India. Journal of Medicinal Plants, Vol. 1, Issue: 4, pp: 21-27.

[20]. Handayani, R., Sulistyo, J. 2008. Sintesis Senyawa Flavonoid- $\alpha$-glikosida secara Reaksi Transglikosilasi Enzimatik dan Aktivitasnya sebagai Antioksidan. Biodiversitas, Vol. 9, No. 1, pp:1-4. 